\title{
Anesthetic management of pregnant women with sickle cell disease - effect on postnatal sickling complications
}

\author{
[Prise en charge anesthésique de femmes enceintes souffrant d'anémie falciforme: \\ effets sur les complications liées à la falciformation postnatale]
}

Julien Camous MD, * Aya N'da MD, ${ }^{*}$ Maryse Etienne-Julan MD, $†$ François Stéphan MD PhD*

\begin{abstract}
Purpose: Currently, there is no consensus regarding the choice of anesthetic technique for parturients with sickle cell disease (SCD). The aim of the study was to determine the impact of the anesthetic technique on the occurrence of postnatal sickling complications.
\end{abstract}

Methods: We reviewed the charts of all pregnant women with SCD who had given birth in our institution between January 2002 and January 2007. Data related to pregnancy and anesthetic management and complications related, or unrelated, to SCD were recorded. Full blood count and lactate dehydrogenase values were recorded on the day of delivery. Risk factors for postnatal sickling complications were evaluated using a logistic regression analysis to estimate odds ratios (OR) and their $95 \%$ confidence intervals $(95 \% \mathrm{Cl})$.

Results: Fourteen of the 55 women (24\%) experienced at least one postnatal sickling complication. Women who developed postnatal sickling complications were found to have a higher leukocyte count $\left(17.0 \pm 6.1 \times 10^{9} \cdot \mathrm{L}^{-1}\right.$ vs $12.8 \pm 4.4 \times 10^{9} \cdot \mathrm{L}^{-1}$, $P=0.008)$ and a lower hemoglobin level $(7.8 \pm 1.1$ vs $8.9 \pm$ I.0 g.dL $\left.\mathrm{dL}^{-1}, P=0.002\right)$. General anesthesia $(\mathrm{OR}=16.0 ; 95 \% \mathrm{Cl}$, I.6 to 165.6$)$ and a leukocyte count $\geq 15 \times 10^{9} \cdot \mathrm{L}^{-1}(\mathrm{OR}=8.4$; $95 \% \mathrm{Cl}, 1.6$ to 44.5 ) were identified as risk factors. Neuraxial anesthesia and use of ephedrine were not identified as risk factors. There were no deaths.

Conclusion: Our study suggests that general anesthesia could be associated with postnatal sickling complications, even when the severity of illness was taken into account.

CAN J ANESTH 2008/55: $5 /$ pp 276-283
Objectif: II n'y a actuellement pas de consensus concernant le choix d'une technique anesthésique pour les parturientes souffrant d'anémie falciforme. L'objectif de cette étude était de déterminer l'impact de la technique anesthésique choisie sur l'incidence des complications liées à la falciformation postnatale.

Méthode : Nous avons passé en revue les dossiers de toutes les femmes enceintes souffrant d'anémie falciforme ayant accouché dans notre centre entre janvier 2002 et janvier 2007. Les données relatives à la grossesse, à la prise en charge anesthésique et aux complications associées ou non à l'anémie falciforme ont été enregistrées. Les valeurs de la formule sanguine et de lacticodéshydrogénase ont été enregistrées le jour de l'accouchement. Les facteurs de risque concernant des complications liées à la falciformation postnatale ont été évalués sur la base d'une analyse de régression logistique à des rapports de cotes estimés (RC) et à leurs intervalles de confiance $95 \%$ (IC à $95 \%$ ).

Résultats : Quatorze des 55 parturientes (24\%) ont montré au moins une complication liée à la falciformation postnatale. Nous avons découvert que les femmes ayant développé des complications liées à la falciformation postnatale avaient une numération des globules blancs plus élevée $(17,0 \pm 6,1 \times$ $10^{9} \cdot \mathrm{L}^{-1}$ vs $\left.12,8 \pm 4,4 \times 10^{9} \cdot \mathrm{L}^{-1}, P=0,008\right)$ et un niveau d'hémoglobine plus bas $\left(7,8 \pm \mathrm{I}, \mathrm{I}\right.$ vs $\left.8,9 \pm \mathrm{I}, 0 \mathrm{~g} \cdot \mathrm{dL}^{-1}, P=0,002\right)$. Une anesthésie générale ( $R C=16,0 ; 1 C$ à $95 \%, I, 6$ à 165,6$)$ et une numération des globules blancs $\geq 15 \times 10^{9} \cdot \mathrm{L}^{-1}(\mathrm{RC}=$ 8,4 ; IC à $95 \%, 1,6$ à 44,5) ont été identifiés comme facteurs de risque. Une anesthésie neuraxiale et l'administration d'éphédrine n'ont pas été identifiés en tant que facteurs de risque. II n'y a pas eu de décès.

From the Department of Anesthesiology, ${ }^{*}$ CHU de Pointe-à-Pitre; and the Caribbean Centre of Sickle Cell Disease "Guy Mérault", $†$ University of French West Indies; Pointe-à-Pitre, France.

Address correspondence to: Pr François Stéphan, Unité de Réanimation chirurgicale adulte, Centre Chirurgical Marie Lannelongue, 133

Avenue de la Résistance 92350 Le Plessis Robinson, France. E-mail to: f-stephan@hotmail.fr

Support was provided solely from institutional and/or departmental sources.

Conflict of interest: None declared.

Accepted for publication December 20, 2007.

Revision accepted February 18, 2008. 
Conclusion: Notre étude suggère que l'anesthésie générale pourrait être associée à des complications liées à la falciformation postnatale et ce, même lorsque la gravité de la maladie a été prise en compte.

W HILE the general care of patients with sickle cell disease (SCD) has improved during the last two decades, ${ }^{1-3}$ pregnancy in women with SCD presents an ongoing challenge for the multidisciplinary team. ${ }^{4-7}$ Sickle-related events occur in about $50 \%$ of women with SCD $, 4,5$ and, specifically, postnatal sickling complications occur in $7.7 \%$ to $31 \%$ of pregnancies in patients with SCD. $4,6,8$ The influence of clinical events and biological factors on the risk of postnatal sickling complications needs to be clarified in this particular setting. The impact of anesthetic technique on the occurrence of sickling complications has been a source of controversy. In a large review of 1,079 anesthetics, the incidence of sickling complications was fourfold higher after regional anesthesia than after general anesthesia $(23.8 \%$ vs $6.6 \%$ for moderate risk procedures, including Cesarean delivery and hysterectomy).${ }^{8}$ However, this study did not control the effect of obstetric procedures, and the result might simply reflect an association with the higher complication rates of obstetrical interventions. On the other hand, neuraxial techniques are preferred to general anesthesia for most Cesarean deliveries. ${ }^{9}$ Nevertheless, no consensus exists concerning the anesthetic care of parturients with SCD. ${ }^{10-13}$

The aim of this retrospective study was to determine the possible relationship between anesthetic technique and the occurrence of postpartum sickling complications.

\section{Patients and methods}

The Research Ethics Board of the CHU Pointe-àPitre approved this study. We reviewed the charts of all pregnant women with SCD who had given birth in our institution between January 2002 and January 2007. Data were prospectively recorded from January 2006 to January 2007.

Charts were evaluated according to the method of Feinstein et al. ${ }^{14}$ Data were abstracted from all charts by means of a standardized form. Baseline characteristics included: age; body mass index; genotype of SCD; medical history related to sickling complications; pre-existing history of arterial hypertension; and diabetes. Data related to pregnancy included: need for blood transfusion; preeclampsia; antepartum hospital admission; gravidity; parity; gestational age at delivery; premature delivery; the course of labour; and the need for Cesarean delivery. Data related to anesthetic management included: the type of anesthesia according to the mode of delivery; perioperative episodes of hypotension and desaturation; use of ephedrine; and the lowest recorded, perioperative body temperature. Laboratory values included full blood count and lactate dehydrogenase (LDH) (normal range 135-225 $\mathrm{UI} \cdot \mathrm{L}^{-1}$ ) recorded at steady state level and the day of delivery. Complications related, or unrelated, to SCD were ascertained by detailed chart review according to the operational definitions reported below.

\section{Patient care}

Women with SCD were evaluated in the department of Obstetrics and Gynecology during the first two months and monthly thereafter, until the eighth month when they were systematically hospitalized. If the women were clinically stable, they were discharged from the hospital and were monitored at home by a midwife on a biweekly basis. Otherwise, hospitalization was maintained. Also, re-hospitalization was scheduled at 40 weeks of gestation. Close supervision during labour was implemented and supplemental oxygen and prophylactic antibiotics were administered. Efforts were made to shorten the duration of labour and delivery. Cesarean delivery was performed for the usual obstetric indications including any evidence of fetal distress. In the postpartum period, low molecular weight heparin was administered and adequate hydration was provided. Incentive spirometry was encouraged. Our approach was to avoid routine prophylactic transfusions for uncomplicated pregnancies, but to consider initiation of transfusions for women who had complications such as preeclampsia, severe anemia, or increasing frequency pain. ${ }^{2}$

Epidural analgesia was initiated with $8-10 \mathrm{~mL} 0.2 \%$ ropivacaine with sufentanil $10 \mu \mathrm{g}$, and analgesia was maintained with an infusion of $0.2 \%$ ropivacaine with $0.5 \mu \mathrm{g} \cdot \mathrm{mL}^{-1}$ sufentanil, at a rate of $8-10 \mathrm{~mL} \cdot \mathrm{hr}^{-1}$. For Cesarean delivery performed under epidural anesthesia, 14 to $20 \mathrm{~mL}$ of $0.75 \%$ ropivacaine with sufentanil $5 \mu \mathrm{g}$ was injected through the catheter. Before spinal anesthesia, all women received an intravenous infusion of $15 \mathrm{~mL} \cdot \mathrm{kg}^{-1}$ lactated Ringer's solution. With the patient in the sitting position, a $25 \mathrm{G}$ Whitacre needle was inserted at the L2-L3 or the L3-L4 interspace, and $0.5 \%$ heavy bupivacaine $2.0-2.5 \mathrm{~mL}$ was injected intrathecally. Next, patients were immediately placed in the recumbent position with left uterine displacement. The techniques to prevent maternal 
TABLE I Baseline characteristics and complications of the 55 patients studied

\begin{tabular}{|c|c|c|c|}
\hline & $\begin{array}{l}\text { All women } \\
(n=55)\end{array}$ & $\begin{array}{l}\text { Women without postnatal } \\
\text { sickling complications } \\
(n=41)\end{array}$ & $\begin{array}{l}\text { Women with postnatal } \\
\text { sickling complications } \\
(n=14)\end{array}$ \\
\hline Age $(\mathrm{yr})$ & $29.2 \pm 5.8$ & $28.5 \pm 6.3$ & $31.1 \pm 3.8$ \\
\hline Body mass index $\left(\mathrm{kg} \cdot \mathrm{m}^{-2}\right)$ & $23.5 \pm 4.9$ & $24.1 \pm 5.1$ & $21.9 \pm 4.1$ \\
\hline \multicolumn{4}{|l|}{ Genotype, $n(\%)$} \\
\hline - SS & $32(58)$ & $21(51)$ & $11(79)$ \\
\hline$-\mathrm{SC}$ & $17(31)$ & $14(34)$ & $3(21)$ \\
\hline$-S-\beta^{+}$thalassemia & $5(9)$ & $5(12)$ & - \\
\hline - S-HPHP & $1(2)$ & $1(2)$ & - \\
\hline \multicolumn{4}{|l|}{ Medical events, $n(\%)$} \\
\hline - Vaso-occlusive crisis & $46(84)$ & $33(80)$ & $13(93)$ \\
\hline - Acute chest syndrome & $9(16)$ & $8(20)$ & $1(7)$ \\
\hline - Cerebrovascular event & $3(5)$ & $3(7)$ & 0 \\
\hline - Diabetes & 0 & 0 & 0 \\
\hline - Hypertension & $1(2)$ & 0 & $1(7)$ \\
\hline Hemoglobin concentration $\left(\mathrm{g} \cdot \mathrm{dL}^{-1}\right)^{*}$ & $9.5 \pm 1.2$ & $9.5 \pm 2.1$ & $9.4 \pm 1.7$ \\
\hline $\mathrm{LDH}$ concentration $\left(\mathrm{UI} \cdot \mathrm{L}^{-1}\right) \dagger$ & $364 \pm 177$ & $350 \pm 175$ & $414 \pm 182$ \\
\hline Hemoglobin F (\%)‡ & $6.8[1.9-13.2]$ & $6.0[1.7-13.1]$ & $7.0[4.0-15.5]$ \\
\hline
\end{tabular}

hypotension included either a prophylactic infusion of ephedrine $60 \mathrm{mg}$ in lactated Ringer's solution 500 $\mathrm{mL}$, or administration of ephedrine boluses $3-6 \mathrm{mg}$ $i v$ in response to hypotension subsequent to neuraxial block. Additional boluses of ephedrine 3 or $6 \mathrm{mg}$ and additional intravenous fluids were administered according to changes in maternal arterial pressure. Neosynephrine was not available at our institution.

For general anesthesia, parturients received thiopental $4 \mathrm{mg} \cdot \mathrm{kg}^{-1}$ iv and succhinylcholine $\mathrm{l} \mathrm{mg} \cdot \mathrm{kg}^{-1}$ iv supplemented with nitrous oxide $50 \%$ and isoflurane. Sufentanil $\left(0.3 \mu \mathrm{g} \cdot \mathrm{kg}^{-1}\right)$ was administered after delivery.

\section{Definitions of clinical events}

A vaso-occlusive crisis was defined as pain in the extremities, the back, the abdomen, the chest, or the head for which no other explanation could be found. ${ }^{8}$ A diagnosis of acute chest syndrome was based on the presence of fever or chest pain combined with new pulmonary infiltrates involving at least one full segment on chest $x$-ray. ${ }^{8}$ Neurologic events included changes in neurologic status accompanied by new neurologic findings (e.g., seizure, coma, or stroke). ${ }^{15}$

Hypotension was defined as systolic blood pressure $<90 \mathrm{mmHg}$, as recorded in the anesthetic chart. ${ }^{16}$ Episodic hypoxemia was deemed to have occurred whenever arterial oxygen saturation $<90 \%$ was recorded in the anesthetic chart. Postoperative bleeding was considered to be present whenever a re-operation for hemorrhage was required, or when two or more red blood cell packs were transfused for a purpose other than for SCD. Nosocomial infections were documented according to the definitions of the Centres for Disease Control. ${ }^{17}$

\section{Statistical considerations}

We hypothesized that the frequency of SCD-related complications was $20 \%$. Assuming at least a threefold increase of postnatal sickling complications between regional and general anesthesia, ${ }^{8}$ we calculated that 40 women were required for the study to have $80 \%$ power, with a two-sided alpha level of $5 \%$ to detect a difference in the incidence of sickling between regional and general anesthesia.

Data were analyzed using Statview 5.0 statistical packages (SAS Institute Inc., Cary, NC, USA). Normality of the distribution of data was assessed by the Kolmogorov-Smirnov test. We expressed continuous variables as the mean $( \pm S D)$ or as the median $\left(25^{\text {th }}-75^{\text {th }}\right.$ percentiles $)$, when appropriate. Categorical variables were compared using the Chi-square test or the Fisher's exact test, and continuous variables were compared using the Student's $t$ test or the MannWhitney U test, when appropriate.

Logistic regression analysis was used to evaluate the potential risk factors for postnatal sickling complications. Variables that were associated with post- 
natal sickling complications in the univariate analysis, and which had a $P$ value $<0.05$, were entered into the model. We differentiated neuraxial analgesia for vaginal delivery and neuraxial anesthesia for Cesarean delivery. Neuraxial analgesia was entered into the model as the reference group. Severity of illness, as reflected by the white cell count, was entered into the model as a potential confounder. The best cutoff value of white cell count was established from a receiver operator characteristics curve. Odds ratio (OR) and 95\% confidence intervals (95\% CI) were calculated for all significant predictors and were used to measure relative risk. Goodness of fit was assessed by the Hosmer and Lemeshow Chi-square test. $\mathrm{R}^{2}$ was used to measure the model performance. Statistical significance was defined as a $P$ value $\leq 0.05$.

\section{Results}

Fifty-six pregnant women with SCD were identified during the study period. Medical charts were only available for 55 of them. The contribution of each year was similar, according to the inclusion criteria and the occurrence of complications $(P=0.49)$. Fortythree women $(78 \%)$ were followed at the Caribbean Centre of Sickle Cell Disease "Guy-Mérault". Baseline main characteristics are shown in Table I. Overall, 42 women developed at least one SCD-related complication during their pregnancy, corresponding to an incidence of 76\% (95\% CI: 65-88\%).

\section{Incidence of postnatal sickling complications}

Fourteen of the 55 women experienced at least one postnatal sickling complication, corresponding to an incidence rate of $24 \%$ (95\% CI: 14-37\%). Postnatal sickling complications (eight acute chest syndrome, six vaso-occlusive crisis, one stroke) occurred at a median of 1.0 day (1.0-2.0). Patients with, or without, postnatal sickling complications were similar with respect to body mass index, medical history of SCD, and steady state levels of hemoglobin and LDH (Table I). However, patients with postnatal sickling complications tended to carry the genotype SS more frequently.

\section{Clinical features during antepartum and intrapar- tum periods, according to the subsequent occurrence of postnatal sickling complications}

Antepartum complications are summarized in Table II. Twenty-eight women developed at least one antepartum, SCD-related complication corresponding to an incidence rate of 51\% (95\% CI: 38-64\%). Patients with postnatal sickling complications tended to have additional SCD-related complications earlier during pregnancy. Although the number of episodes of infection during pregnancy was not different between groups, the median delay of occurrence before delivery was shorter in parturients who ultimately developed postnatal sickling complications. One-third of women in each group received a median of 2 units of packed red blood cells before delivery.

Intrapartum characteristics are reported in Table III. Women with postnatal sickling complications were more often managed by Cesarean delivery. Indications for Cesarean delivery were also different between the two groups. Full blood count and LDH measurements were obtained on the day of delivery. Full blood count was missing for one patient with, and four patients without, postnatal sickling complications. Lactate dehydrogenase values were missing in six patients (one with postnatal sickling complications). Women who developed postnatal sickling complications were found to have a higher leukocyte

TABLE II Antepartum complications according to the subsequent occurrence of postnatal sickling complications

\begin{tabular}{|c|c|c|c|}
\hline & $\begin{array}{l}\text { Women without postnatal } \\
\text { sickling complications } \\
(n=41)\end{array}$ & $\begin{array}{l}\text { Women with postnatal } \\
\text { sickling complications } \\
(n=14)\end{array}$ & P value \\
\hline \multicolumn{4}{|l|}{ Sickle cell disease-related complications } \\
\hline - Vaso-occlusive crisis and/or acute chest syndrome, $n(\%)$ & $18(44)$ & $10(71)$ & 0.08 \\
\hline - Median delay between occurrence and delivery (days) & $28.0(10.0-68.0)$ & $14.0(5.5-23.5)$ & 0.15 \\
\hline Blood transfusion before delivery, $n(\%)$ & $13(32)$ & $5(36)$ & 0.78 \\
\hline Preeclampsia, $n(\%)$ & $2(5)$ & $1(7)$ & 0.75 \\
\hline Infections, $n(\%)$ & $11(27)$ & $4(29)$ & 0.99 \\
\hline - Urinary tract infection & $6(15)$ & $2(14)$ & \\
\hline - Bacterial vaginosis & $3(7)$ & $1(7)$ & \\
\hline - Bronchitis & $2(5)$ & 0 & \\
\hline - Undetermined sepsis & 0 & $1(7)$ & \\
\hline Median delay between onset and delivery (days) & $113(28-148)$ & $14(6-21)$ & 0.02 \\
\hline Antepartum hospital admission $n(\%)$ & $36(88)$ & $14(100)$ & 0.31 \\
\hline
\end{tabular}


TABLE III Profile of pregnancy according to the subsequent occurrence of postnatal sickling complications

\begin{tabular}{llll}
\hline & $\begin{array}{l}\text { Women without postnatal } \\
\text { sickling complications } \\
(n=41)\end{array}$ & $\begin{array}{l}\text { Women with postnatal } \\
\text { sickling complications } \\
(n=14)\end{array}$ & P value \\
\hline Median gravidity & $2.0(1.0-3.0)$ & $2.5(1.0-4.0)$ & 0.46 \\
Median parity & $0.0(0.0-1.0)$ & $1.0(0.0-2.0)$ & 0.28 \\
Gestational age at delivery (week) & $37.6 \pm 2.7$ & $6.6 \pm 2.9$ & 0.24 \\
Premature delivery (<37 week), $n(\%)$ & $7(17)$ & $4(29)$ & 0.07 \\
Inducing labour, $n$ (\%) & $16(40)$ & $370 \pm 172$ & 0.44 \\
Mean duration of labour (min) & $276 \pm 125$ & $11(79)$ & 0.13 \\
Cesarean delivery, $n(\%)$ & $15(37)$ & $5(45)$ & $<0.01$ \\
Indications for Cesarean delivery, $n(\%)$ & $14(93)$ & $6(55)$ & \\
- Obstetric indications & $1(7)$ & & \\
- Fetal distress & &
\end{tabular}

TABLE IV Anesthetic management

\begin{tabular}{|c|c|c|c|}
\hline & $\begin{array}{l}\text { Patients } \\
\text { without } \\
\text { postnatal } \\
\text { sickling } \\
\text { complications } \\
(n=41)\end{array}$ & $\begin{array}{l}\text { Patients } \\
\text { with } \\
\text { postnatal } \\
\text { sickling } \\
\text { complications } \\
(n=14)\end{array}$ & $P$ value \\
\hline \multicolumn{4}{|l|}{ Anesthetic techniques } \\
\hline Epidural analgesia & $21(51)$ & $2(14)$ & $<0.01$ \\
\hline \multicolumn{4}{|c|}{ for Cesarean delivery, $n(\%)$} \\
\hline - epidural & $3(7)$ & $1(7)$ & \\
\hline - spinal* & $11(27)$ & $5(36)$ & \\
\hline General anesthesia, $n(\%)$ & $3(7)$ & $5(36)$ & \\
\hline $\begin{array}{l}\text { Peripartum episodes of } \\
\text { arterial hypotension, } n(\%)\end{array}$ & $10(24)$ & $4(29)$ & 0.74 \\
\hline $\begin{array}{l}\text { Peripartum episodes of } \\
\text { desaturation, } n(\%)\end{array}$ & $2(5)$ & $1(7)$ & 0.99 \\
\hline Use of ephedrine, $n(\%)$ & $8(19)$ & $8(57)$ & 0.02 \\
\hline $\begin{array}{l}\text { Perioperative blood } \\
\text { transfusion, } n(\%)\end{array}$ & $2(5)$ & $2(14)$ & 0.27 \\
\hline $\begin{array}{l}\text { Lowest perioperative } \\
\text { body temperature }\left({ }^{\circ} \mathrm{C}\right)\end{array}$ & $36.2 \pm 0.8$ & $36.2 \pm 0.8$ & 0.99 \\
\hline
\end{tabular}

count $\left(17.0 \pm 6.1 \times 10^{9} \cdot \mathrm{L}^{-1}\right.$ vs $12.8 \pm 4.4 \times 10^{9} \cdot \mathrm{L}^{-1}$, $P<0.01)$ and a lower hemoglobin level $(7.8 \pm 1.1 \mathrm{vs}$ $\left.8.9 \pm 1.0 \mathrm{~g} \cdot \mathrm{dL}^{-1}, P<0.01\right)$ than those who remained free of events. They also had a higher LDH level $(910$ \pm 686 vs $487 \pm 248$ UI $\left.\cdot \mathrm{L}^{-1}, P=0.002\right)$.

\section{Anesthetic management}

Anesthetic management was different between the two groups (Table IV). General anesthesia for fetal distress was performed in three cases and once in patients with and without postnatal sickling complications, respec-
TABLE V Overall predictors of postnatal sickling complications

\begin{tabular}{ll}
\hline Risk factors & $\begin{array}{l}\text { Odds ratio } \\
\text { (95\% confidence interval) }\end{array}$ \\
\hline General anesthesia & $16.0(1.6-165.6)$ \\
Leukocyte count $\geq 15 \times 10^{9} \cdot \mathrm{L}^{-1}$ & $8.4(1.6-44.5)$ \\
Neuraxial anesthesia & $2.9(0.2-35.5)$ \\
Use of ephedrine & $3.7(0.5-27.8)$ \\
\hline
\end{tabular}

The goodness of fit Chi-square of this model remained non significant $(P=0.07)$. The model explained $32 \%$ of the variance in the data $\left(\mathrm{R}^{2}=0.32\right)$.

tively $(P=0.99)$. Due to a shortage of time, epidural analgesia could be not performed in three patients without, and in one patient with, postnatal sickling complications $(P=0.99)$. Although perioperative episodes of arterial hypotension or desaturation were not linked to postnatal sickling complications, administration of ephedrine was significantly more frequent for parturients with postnatal sickling complications than for those without. Median administered doses were $60 \mathrm{mg}(51-61)$ ps $9 \mathrm{mg}(9-50)(P=0.03)$ for patients with and without postnatal sickling complications, respectively. A logistic regression analysis was performed, taking into account anesthetic variables univariately associated with postnatal sickling complications (anesthetic techniques according to the mode of delivery and use of ephedrine) and leukocyte count as a marker of severity of illness. The cut-off value was set at $\geq 15 \times 10^{9} \cdot \mathrm{L}^{-1}$, after analysis of receiver operator characteristics curve. General anesthesia $(\mathrm{OR}=16.0$; $95 \%$ CI, 1.6 to 165.6 ) and a leukocyte count $\geq 15 \times$ $10^{9} \cdot \mathrm{L}^{-1}(\mathrm{OR}=8.4 ; 95 \% \mathrm{CI}, 1.6$ to 44.5$)$ were identified as risk factors (Table V). 


\section{Postnatal non-sickling complications and outcome}

In the postpartum period, a high percentage of patients with postnatal sickling complications received blood transfusion (38 vs $2 \%, P<0.01$ ). Postoperative bleeding occurred in one patient with, and two patients without, postnatal sickling complications $(7.1 \%$ vs $4.9 \% ; P=0.75)$. One woman without postnatal sickling complications developed a urinary tract infection, and another patient developed endometritis.

There were no deaths. The development of postnatal sickling complications was associated with an increased length of total hospital stay [ 16 days (12.0 to 23.0$)$ vs 9.0 days $(6.0$ to 12.0$) ; P<0.01]$ and an increased length of hospital stay after delivery [9.5 days ( 7.0 to 14.0$)$ vs 5.0 days (4.0 to 7.0$) ; P<$ $0.0001]$.

\section{Discussion}

Our study showed that, in a series of 55 parturients with SCD, one quarter of patients experienced sickling complications after delivery. General anesthesia was a risk factor for postnatal sickling complications, even when the severity of illness was taken into account, whereas neuraxial anesthesia was not identified as such.

Pregnancy for women with SCD is still characterized by a high rate of complications, ${ }^{4-7}$ particularly for homozygous SCD. ${ }^{5,6}$ Fifty percent to $88 \%$ of pregnant women experienced sickling complications, ${ }^{4-6}$ but the rate of painful episodes of homozygote for the $\beta^{\text {s }}$ globin women was probably not adversely affected by their pregnancy. ${ }^{5}$ In a multicentre survey in the United Kingdom involving 81 pregnancies, postnatal sickling complications occurred in $7.7 \%$ of patients; ${ }^{4}$ furthermore, for the cooperative study of SCD analysing 83 patients who underwent Cesarean section and hysterectomy, postnatal sickling complications occurred in $17 \%$ of patients. ${ }^{8}$ We reported a rate of $25 \%$ in our series. Interestingly, a previous study including 68 pregnancies in Guadeloupe from 1993 to 1997 reported a rate of $31 \%{ }^{6}$ Of the population studied, the compliance with antenatal care, the potential impact of environmental factors, and the mode of delivery could account for such differences. Interestingly, such complications occurred the day after delivery, which identified the importance of the intrapartum period and its management.

No consensus exists concerning the anesthetic care of parturients with SCD. ${ }^{2,10-13}$ In a review on SCD and anesthesia published in 1988, the authors stated that, "the choice of regional or general anesthesia for obstetric patients depends on the patient's general condition and the preference of the anesthesiologist, rather than specific indication". ${ }^{10}$ According to others, regional anesthesia could be safely used for Cesarean delivery. ${ }^{11}$ However, it was suggested, in a large study, that regional anesthesia may be associated with higher sickling complications. ${ }^{8}$ Even though several possible selection biases were not taken into account in this study, ${ }^{8}$ the results challenged conventional thinking.

The mode of delivery is an important factor to consider when analyzing the impact of anesthetic technique. We observed a significant difference in the rates and the indications for Cesarean delivery between the uncomplicated $v s$ the complicated groups. The rate of Cesarean delivery in the SCD population is generally higher than in the whole population, ${ }^{4,6,18}$ and it varies widely amongst studies, with rates ranging from 15 to $59 \%{ }^{4,6,7,18}$ In our study, this rate was $47 \%$. These results suggest that general anesthesia was a risk factor for the occurrence of postnatal sickling complications, while neuraxial anesthesia was not identified as such. The American Society of Anesthesiologists Task Force on Obstetric Anesthesia identifies that general anesthesia increases maternal complications. ${ }^{9}$ General anesthesia is associated with a higher risk of failed tracheal intubation with the entire maternal population than with non-obstetrical patients, and the risk of maternal death with general anesthesia is 17 times greater than that associated with regional anesthesia. ${ }^{9}$ Also, there are several, potential advantages to performing regional anesthesia for labour and delivery in SCD patients. Regional anesthesia could be beneficial for SCD patients by inducing vasodilation and enhanced blood flow in the anesthetized area, and by providing optimal pain control. Interestingly, epidural analgesia has been described to treat the unusual occurrence of a vaso-occlusive crisis during labour. ${ }^{11}$ However, general anesthesia may be the most appropriate choice in some circumstances, including fetal bradycardia. ${ }^{9}$ One approach could be the early insertion of an epidural catheter to reduce the need for general anesthesia in such a high-risk population. ${ }^{9}$

Whatever the choice of anesthetic technique, it is important to avoid hypothermia, hypoxemia, hypovolemia, acidosis, and hypotension. ${ }^{1,10-13}$ Ephedrine is an acceptable drug for normalizing blood pressure. ${ }^{9}$ It has been speculated that pressors, which can produce vasoconstriction and stasis, should be avoided whenever possible in $\mathrm{SCD},{ }^{10}$ because these conditions may increase the risk of sickling. ${ }^{3,13}$ Apart from its vasoconstrictive effect, ephedrine, like epinephrine, ${ }^{20}$ could also initiate or exacerbate vaso-occlusion via activation of red cell adhesion. ${ }^{20}$ Increased sickle erythrocyte adhesion to the endothelium has been postulated to be an important factor in the initiation and/or pro- 
gression of vaso-occlusive crises. ${ }^{3,13,20}$ However, the use of ephedrine was not identified as a risk factor for postnatal sickling complications.

We have studied several biological variables that could be considered as surrogates of the severity of illness in SCD. A low hemoglobin level $\left(\leq 7.1 \mathrm{~g} \cdot \mathrm{dL}^{-1}\right)$ had previously been shown to correlate with an increased risk of pain, ${ }^{22}$ stroke, ${ }^{15}$ and death in adulthood. ${ }^{21}$ However, there was no correlation between the degree of anemia in women with SCD and obstetrical or perinatal complications. ${ }^{5,7}$ A high baseline white-cell count has been associated with an increased risk of early death, ${ }^{21}$ acute chest syndrome, ${ }^{23}$ and neurological complications. ${ }^{15} \mathrm{~A}$ recent study also showed an association between high, steady-state, white-cell count and the severity of SCD in pregnancy. ${ }^{24}$ Our results are in accordance with these studies and consistent with the role of leukocytes in the pathophysiology of SCD. ${ }^{3}$ Elevated serum LDH levels were associated with low levels of hemoglobin and with a blunted vasodilation response to nitric oxide. ${ }^{25}$ Interestingly, elevated $\mathrm{LDH}$ was also reported during acute chest syndrome. ${ }^{23}$ We have chosen to enter the white-cell count into the logistic regression model instead of recording hemoglobin or $\mathrm{LDH}$ levels, because there was less missing data, and the clinical course of these patients was little altered by transfusion.

Our study has several limitations, mainly due to its retrospective design. Firstly, it is acknowledged that retrospective identification of complications depends on the detail and the completeness of the medical record. To minimize this factor, the analysis was limited to postoperative complications thought to be clinically significant, thus unlikely to be omitted from the medical record. Secondly, several confounding variables could not have been controlled, due to the relatively small sample of patients. However, the major confounders were taken into account in the logistic regression analysis. Thirdly, one cannot show causality from a retrospective study, only association that may be causal. Fourthly, there were some missing data, which may also have influenced the statistical power and may have caused bias. However, the deleted cases are a relatively small proportion of the entire data set. Regardless, due to the limited power of the study, a negative finding should be interpreted with caution. Finally, the study was performed at a single medical centre, and the results may not be generalizable to other institutions.

In conclusion, our study suggests that general anesthesia could be associated with postnatal sickling complications, even when the severity of illness is taken into account, and efforts must be made to promote neuraxial anesthesia in parturients with SCD.

\section{References}

l Steinberg MH. Management of sickle cell disease. N Engl J Med 1999; 340: 1021-30.

2 National Institutes of Health, National Heart, Lung, and Blood Institute, and Division of Blood Diseases and resources. The Management of Sickle Cell Disease, $4^{\text {th }}$ ed. Bethesda: NIH Publication No 02-2117; 2002.

3 Stuart MJ, Nagel RL. Sickle-cell disease. Lancet 2004; 364: 1343-60.

4 Howard RJ, Tuck SM, Pearson TC. Pregnancy in sickle cell disease in the UK: results of a multicentre survey of the effect of prophylactic blood transfusion on maternal and fetal outcome. Br J Obstet Gynaecol 1995; 102: 947-51.

5 Smith JA, Espeland M, Bellevue R, Bonds D, Brown AK, Koshy M. Pregnancy in sickle cell disease: experience of the Cooperative Study of Sickle Cell Disease. Obstet Gynecol 1996; 87: 199-204.

6 Leborgne-Samuel $\Upsilon$, Janky E, Venditelli $F$, et al. Drépanocytose et grossesse: revue de 68 observations en Guadeloupe. J Gynecol Obstet Biol Reprod (Paris) 2000; 29: 86-93.

7 Serjeant GR, Loy LL, Crowther M, Hambleton IR, Thame M. Outcome of pregnancy in homozygous sickle cell disease. Obstet Gynecol 2004; 103: 1278-85.

8 Koshy M, Weiner SJ, Miller ST, et al. Surgery and anesthesia in sickle cell disease. Cooperative Study of Sickle Cell Diseases. Blood 1995; 86: 3676-84.

9 American Society of Anesthesiologists Task Force on Obstetric Anesthesia. Practice guidelines for obstetric anesthesia: an updated report by the American Society of Anesthesiologists Task Force on Obstetric Anesthesia. Anesthesiology 2007; 106: 843-63.

10 Esseltine DW, Baxter MR, Bevan JC. Sickle cell states and the anaesthetist. Can J Anaesth 1988; 35: 385403.

11 Danzer BI, Birnbach DJ, Thys DM. Anesthesia for the parturient with sickle cell disease. J Clin Anesth 1996; 8: 598-602.

12 Firth $P G$, Head $C A$. Sickle cell disease and anesthesia. Anesthesiology 2004; 101: 766-85.

13 Firth PG. Anaesthesia for peculiar cells. A century of sickle cell disease. Br J Anaesth 2005; 95: 287-99.

14 Feinstein AR, Pritchett JA, Schimpff CR. The epidemiology of cancer therapy. IV. The extraction of data from medical records. Arch Intern Med 1969; 123: 571-90.

15 Prengler M, Pavlakis SG, Prohovnik I, Adams RJ. Sickle cell disease: the neurological complications. Ann Neurol 2002; 51: 543-52.

16 Jackson R, Reid JA, Thorburn J. Volume preloading is not essential to prevent spinal-induced hypotension at caesarean section. Br J Anaesth 1995; 75: 262-5. 
17 Garner JS, Jarvis WR, Emori TG, Horan TC, Hughes $J M$. CDC definitions for nosocomial infections. In: Olmsted RN (Ed). APIC Infection Control and Applied Epidemiology: Principles and Practice. St. Louis: Mosby; 1996: A-1-A-20.

18 Koshy M, Burd L, Wallace D, Moawad A, Baron J. Prophylactic red-cell transfusions in pregnant patients with sickle cell disease. A randomized cooperative study. N Engl J Med 1988; 319: 1447-52.

19 Eltzschig HK, Lieberman ES, Camann WR. Regional anesthesia and analgesia for labor and delivery. N Engl J Med 2003; 348: 319-32.

20 Zennadi R, Hines PC, De Castro LM, Cartron JP, Parise LV, Telen MJ. Epinephrine acts through erythroid signaling pathways to activate sickle cell adhesion to endothelium via $\mathrm{LW}$-alphavbeta3 interactions. Blood 2004; 104: 3774-81.

21 Platt OS, Brambilla DJ, Rosse WF, et al. Mortality in sickle cell disease. Life expectancy and risk factors for early death. N Engl J Med 1994; 330: 1639-44.

22 Platt OS, Thorington BD, Brambilla DJ, et al. Pain in sickle cell disease. Rates and risk factors. N Engl J Med 1991; 325: 11-6.

23 Maitre B, Habibi A, Roudot-Thoraval F, et al. Acute chest syndrome in adults with sickle cell disease.

Therapeutic approach, outcome, and results of BAL in a monocentric series of 107 episodes. Chest 2000; 117: 1386-92.

24 Litos M, Sarris I, Bewley S, Seed P, Okpala I, OtengNtim E. White blood cell count as a predictor of the severity of sickle cell disease during pregnancy. Eur J Obstet Gynecol Reprod Biol 2007; 133: 169-72.

25 Kato GJ, McGowan V, Machado RF, et al. Lactate dehydrogenase as a biomarker of hemolysis-associated nitric oxide resistance, priapism, leg ulceration, pulmonary hypertension, and death in patients with sickle cell disease. Blood 2006; 107: 2279-85. 